\title{
A COMPARISON OF ELEVEN GENERAL ANAESTHETICS ADMINISTERED WITH 7.5 PER CENT CARBON DIOXIDE DURING SPONTANEOUS BREATHING
}

\author{
Alien B. Dobkin, Peter H. Byles, Benjamin F. Africa, and Ashley A. Levy
}

EvIDENCE has accumulated to show that hypercapnia has serious adverse effects both in the conscious state and during anaesthesia. ${ }^{1,2,3}$ Nevertheless, a mild degree of hypercapnia $\left(\mathrm{P}_{\mathrm{CO}_{2}} \sim 65\right)$ has been found useful during certain surgical procedures, particularly in patients with extensive arteriosclerosis ${ }^{4}$ during deliberate induced deep hypothermia ${ }^{5}$ and during anaesthesia for carotid endarterectomy, ${ }^{8}$ because it may prevent tissue and cerebral hypoxia, ${ }^{7,8}$

In our previous reports of anaesthesia with added carbon dioxide, no appreciable alterations in cardiovascular dynamics and metabolic functions were observed when pulmonary ventilation was controlled. ${ }^{9,10}$ Since it was found that enflurane and isoflurane are potent respiratory depressants at a surgical depth of anaesthesia, this study was devised to determine the physiological and metabolic effects of these two anaesthetics when carbon dioxide was added, and spontaneous breathing was permitted. The responses with nine other general anaesthetics were also studied for comparison.

\section{Materials AND Methods}

Serial crossover tests were done on 18 large, trained, healthy, male, mongrel dogs (19 to $31 \mathrm{~kg}$ ) at two-week intervals, employing the eleven anaesthetic agents shown in Table I. Each agent was used at least six times and each animal was anaesthetized with four different agents. A high protein diet was provided for one month prior to testing and during the intervals between tests.

In each of 72 experiments, an unpremedicated dog, fasted overnight, was weighed first and then an 18-gauge plastic cannula was inserted in a fore-leg vein and $20 \mathrm{mg} / \mathrm{kg}$ thiopentone ( 2 per cent) was administered slowly. The dog was laid on its side. The cannula was attached to a regulated infusion of 0.9 per cent saline. A cuffed tracheal tube ( 40 French) was inserted without using a muscle relaxant and attached to a non-rebreathing type anaesthetic circuit delivering a gas mixture containing 50 per cent $\mathrm{N}_{2} \mathrm{O}, 7.5$ per cent $\mathrm{CO}_{2}$ and 42.5 per cent $\mathrm{O}_{2}$. The animal was allowed to breathe spontaneously and a respirometer was used to measure minute ventilation and respiratory rate. A femoral artery was cannulated percutaneously and the cannula was attached to a Statham strain gauge and Grass Polygraph through a 3-way stopcock to allow for blood sampling. ECG (lead II) was recorded on the polygraph. A rectal telethermometer probe (Yellow Springs Instrument Co., Inc.) and a urinary catheter attached to a calibrated gravity trap were also inserted. Following these preparations, venous and arterial blood

From the Department of Anesthesiology, State University of New York, Upstate Medical Center, Syracuse, New York, 13210, U.S.A. 
TABLE I

Anaesthetic Agents and Vapourisers used for 90 minutes Following Induction with ThIOPENTONE $20 \mathrm{mg} / \mathrm{kg}$, I.V.; HYPERCAPNIA WITh 7.5 PER CENT Carbon DiOXIDE (SPONTANEOUS BREATHING)

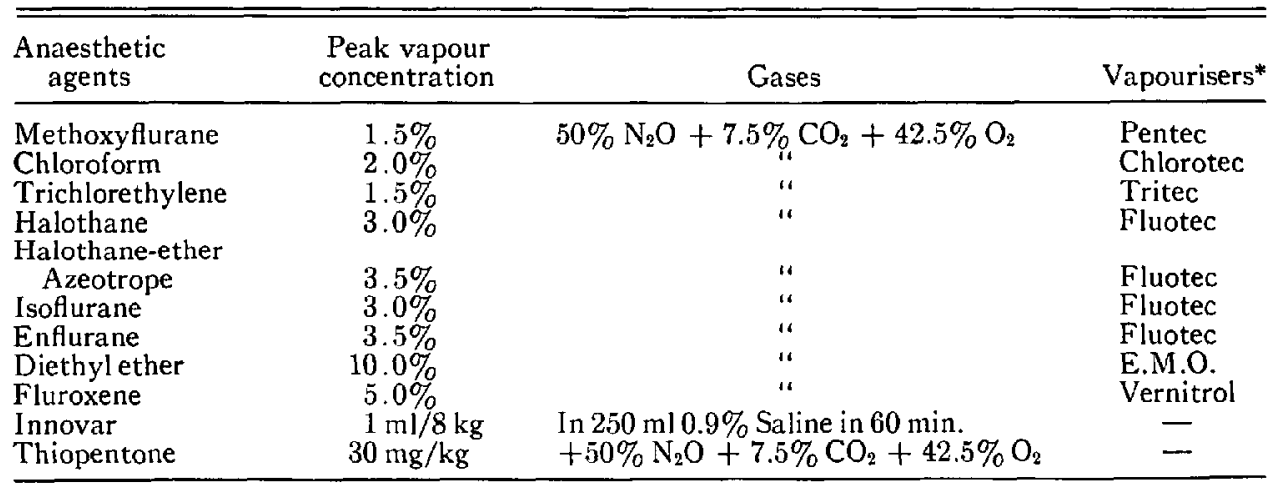

*Vapourisers were calibrated for each anaesthetic and checked by gas chromatography.

EXPERIMENTAL ARRANGEMENT TO STUDY EFFECT OF GENERAL ANAESTHESIA WITH $\mathrm{N}_{2} \mathrm{O}(50 \%)$ AND $\mathrm{CO}_{2}(7.5 \%)$ ON CARDIORESPIRATORY OYNAMICS AND BLOOD CHEMISTRY

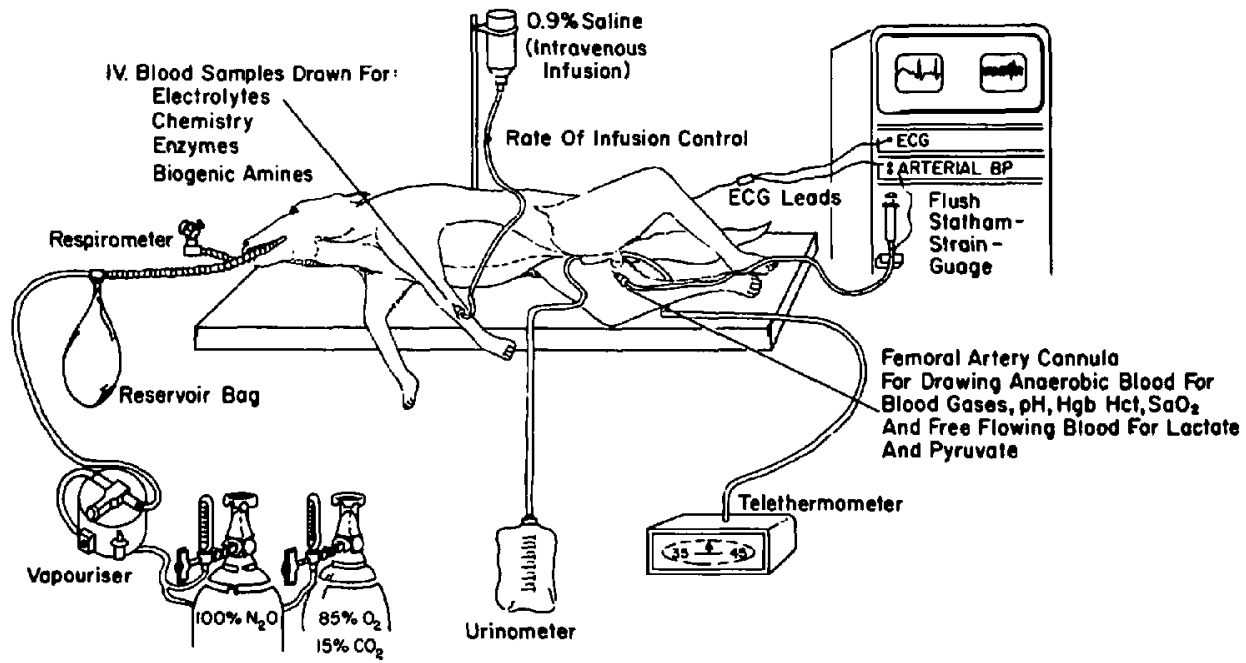

Figure 1. Illustration of laboratory procedure for evaluating response to carbon dioxide during general anaesthesia.

samples were drawn for control measurements (Figure 1). At this time, the maintenance agents were begun. With the nine inhalation agents, the vapour concentration was gradually increased over the first 60 minutes to the maximum concentration selected, and then maintained at that level for the remaining 30 minutes of the test. With the parenteral anaesthetics (thiopentone and Innovar), the total infusion dose was given over 60 minutes, and then saline only was administered during the remaining 30 minutes. All experiments were done in the morning during the summer months. The ambient temperature of the laboratory was kept warm $\left(23^{\circ} \mathrm{C}\right.$ to $\left.25^{\circ} \mathrm{C}\right)$. 
At the end of the test period, venous and arterial blood samples were drawn again and total urine output and saline infusion volumes were recorded. All anaesthetics were discontinued and 100 per cent oxygen was given until the animal no longer tolerated intubation. All recording equipment and the tracheal tube were then removed promptly. The dog was kept under direct surveillance until it was fully ambulant and had a steady gait. During each experiment, recordings of the ECG, heart rate, arterial blood pressure, respiratory rate, minute volume, urine output, saline infusion and inhaled vapour concentrations were charted every five to ten minutes. Notes were kept of clinical events during anaesthesia and recovery.

\section{Laboratory Procedures}

Anaerobic arterial blood samples were analyzed on an Instrumentation Laboratories Inc., Model 113, for $\mathrm{pH}, \mathrm{Pa}_{\mathrm{CO}_{2}}$ and $\mathrm{Pa}_{2}$ at $37^{\circ} \mathrm{C}$. Oxygen saturation of these samples was determined with a reflection oximeter made by American Optical Company; haematocrit was measured by a micromethod, and haemoglobin was determined by the cyanmethaemoglobin method. Free-flowing arterial blood was collected to determine lactate and pyruvate by the method of Neville and Gelder. ${ }^{11}$ Blood sugar, serum inorganic phosphorus, bilirubin, calcium, potassium, sodium, blood urea nitrogen, creatinine, transaminases and urinalysis were done by standard laboratory methods. Biogenic amines were measured by methods using the Aminco Bowman spectrophotofluorometer with a fluoro-micro-photometer, described previously. ${ }^{12}$ Blood insulin levels were determined by an immunoassay method. ${ }^{13}$

\section{Results}

\section{Cardiovascular Effects, Electrocardiogram and Urine Output (Table II)}

Hypotension developed early ( $>25 \%)$ and persisted with methoxyflurane, halothane, halothane-ether azeotrope, isoflurane, enflurane and Innovar. Bradycardia occurred with the same agents, except methoxyflurane. Chloroform, trichlorethylene, diethyl ether, fluroxene and thiopentone did not cause depression of arterial blood pressure. Tachycardia occurred with trichlorethylene, diethyl ether and fluroxene. Cardiac arrhythmias seldom appeared with any of the agents and were not persistent. Urine output was adequate during anaesthesia with all the agents ( $>40 \mathrm{ml}$ in 90 minutes). Rectal temperature fell $<2^{\circ} \mathrm{C}$ in all experiments.

\section{Pulmonary Ventilation(Table III)}

The addition of carbon dioxide either reduced the respiratory depression ordinarily caused by a surgical depth of general anaesthesia, or increased the respiratory rate and minute volume with all the anaesthetics except with methoxyflurane, halothane, isoflurane and enflurane. The most striking stimulation of pulmonary ventilation occurred with chloroform, diethyl ether, fluroxene, Innovar and thiopentone.

Blood Gases, pH, Plasma Bicarbonate, Base Excess and Haematocrit (Table IV)

All animals had some metabolic acidosis to begin with because of overnight 
TABLE II

Summary of Changes in Mean Arterial Blood Pressure (torr), Heart Rate (per minute), Urine OUtPut ( $\mathrm{ml}$ ) and 0.9 per cent Saline (ml) Administered During Administration of General Anaesthesia with AdDed 7.5 per cent Carbon Dioxide (SPONTANEOUS BREATHING)

\begin{tabular}{|c|c|c|c|c|c|}
\hline Minutes & 0 & 30 & 60 & 90 & $\begin{array}{c}\text { Saline in } \\
\text { urine out } \\
\mathrm{ml}\end{array}$ \\
\hline Methoxyflurane & $\begin{array}{l}* 141 \\
\dagger 150\end{array}$ & $\begin{array}{l}115 \\
150\end{array}$ & $\begin{array}{l}103 \\
160\end{array}$ & $\begin{array}{r}91 \\
152\end{array}$ & $\begin{array}{r}179 \\
64\end{array}$ \\
\hline Chloroform & $\begin{array}{l}125 \\
148\end{array}$ & $\begin{array}{l}132 \\
153\end{array}$ & $\begin{array}{l}135 \\
158\end{array}$ & $\begin{array}{l}134 \\
150\end{array}$ & $\begin{array}{r}125 \\
99\end{array}$ \\
\hline Trichlorethylene & $\begin{array}{l}134 \\
118\end{array}$ & $\begin{array}{l}132 \\
177\end{array}$ & $\begin{array}{l}122 \\
166\end{array}$ & $\begin{array}{l}124 \\
168\end{array}$ & $\begin{array}{r}193 \\
55\end{array}$ \\
\hline Halothane & $\begin{array}{l}143 \\
151\end{array}$ & $\begin{array}{l}111 \\
138\end{array}$ & $\begin{array}{r}91 \\
131\end{array}$ & $\begin{array}{r}82 \\
141\end{array}$ & $\begin{array}{r}203 \\
55\end{array}$ \\
\hline $\begin{array}{l}\text { Halothane-ether } \\
\text { Azeotrope }\end{array}$ & $\begin{array}{l}129 \\
146\end{array}$ & $\begin{array}{l}103 \\
124\end{array}$ & $\begin{array}{r}97 \\
127\end{array}$ & $\begin{array}{r}82 \\
127\end{array}$ & $\begin{array}{r}220 \\
81\end{array}$ \\
\hline Isoflurane & $\begin{array}{l}149 \\
170\end{array}$ & $\begin{array}{r}90 \\
146\end{array}$ & $\begin{array}{l}111 \\
147\end{array}$ & $\begin{array}{l}100 \\
136\end{array}$ & $\begin{array}{l}192 \\
114\end{array}$ \\
\hline Enflurane & $\begin{array}{l}134 \\
138\end{array}$ & $\begin{array}{l}102 \\
137\end{array}$ & $\begin{array}{l}103 \\
130\end{array}$ & $\begin{array}{r}95 \\
123\end{array}$ & $\begin{array}{r}170 \\
71\end{array}$ \\
\hline Diethyl ether & $\begin{array}{l}120 \\
126\end{array}$ & $\begin{array}{l}139 \\
220\end{array}$ & $\begin{array}{l}140 \\
206\end{array}$ & $\begin{array}{l}140 \\
198\end{array}$ & $\begin{array}{r}168 \\
53\end{array}$ \\
\hline Fluroxene & $\begin{array}{l}133 \\
134\end{array}$ & $\begin{array}{l}130 \\
149\end{array}$ & $\begin{array}{l}143 \\
164\end{array}$ & $\begin{array}{l}142 \\
166\end{array}$ & $\begin{array}{r}150 \\
43\end{array}$ \\
\hline Innovar & $\begin{array}{l}128 \\
135\end{array}$ & $\begin{array}{l}82 \\
77\end{array}$ & $\begin{array}{l}88 \\
75\end{array}$ & $\begin{array}{l}90 \\
98\end{array}$ & $\begin{array}{r}241 \\
83\end{array}$ \\
\hline Thiopentone & $\begin{array}{l}128 \\
131\end{array}$ & $\begin{array}{l}135 \\
142\end{array}$ & $\begin{array}{l}142 \\
154\end{array}$ & $\begin{array}{l}145 \\
158\end{array}$ & $\begin{array}{r}261 \\
78\end{array}$ \\
\hline
\end{tabular}

* Mean arterial blood pressure.

†Mean heart rate per minute.

fasting. In spite of the appearance of respiratory stimulation, respiratory acidosis developed with all the anaesthetics during the tests. The $\mathrm{pH}$ usually fell from 7.35 to 7.15 , while $\mathrm{Pa}_{\mathrm{CO}_{2}}$ usually rose from 40 to 65 torr. This was partly due to the addition of hydrogen ion formed from the added carbon dioxide and partly due to increased deadspace ventilation due to tachypnoea, especially with chloroform and trichlorethylene. The least respiratory acidosis developed with diethyl ether, which caused the most metabolic acidosis (base excess $-8 \mathrm{mEq} / \mathrm{l}$ ) and an appreciable rise in the haematocrit and haemoglobin. Oxygen tension in the blood was not appreciably affected and remained in the range expected in dogs receiving about 40 per cent oxygen.

\section{Electrolytes and Other Laboratory Tests (Table V)}

Serum sodium, calcium, urea nitrogen, creatinine, bilirubin and transaminases showed small variations within the normal range. All the anaesthetics caused an elevation of the blood sugar of at least 20 per cent above control values. Serum potassium was reduced with all agents except isoflurane and enflurane, but the changes were not significant. Serum inorganic phosphorus consistently rose appreciably during anaesthesia with all agents. 
TABLE III

Summary of Alterations in Minute Volume of Breathing (litres) and Respiration Rate (PER minute) During Administration of General Anaesthesia with Added 7.5 per cent Carbon Dioxide (spontaneous breathing)

\begin{tabular}{|c|c|c|c|c|c|c|}
\hline Minutes & 0 & 10 & 20 & 30 & 60 & 90 \\
\hline Methoxyflurane & ${ }^{4.3^{*}}$ & $13^{7.8}$ & $13^{7.2}$ & 13 & $1^{5.5}$ & 13.6 \\
\hline Chloroform & $\begin{array}{l}2.4 \\
9\end{array}$ & ${ }^{7.2}$ & $\begin{array}{l}11.4 \\
18\end{array}$ & $\begin{array}{l}13.9 \\
25\end{array}$ & $\begin{array}{l}16.5 \\
35\end{array}$ & $\begin{array}{l}15.5 \\
36\end{array}$ \\
\hline Trichlorethylene & 13.9 & $\begin{array}{l}10.5 \\
23\end{array}$ & $\begin{array}{l}12.1 \\
25\end{array}$ & $\begin{array}{l}15.2 \\
33\end{array}$ & $\begin{array}{l}16.0 \\
55\end{array}$ & $\begin{array}{l}16.1 \\
63\end{array}$ \\
\hline Halothane & $\begin{array}{c}4.2 \\
13\end{array}$ & $\begin{array}{l}5.3 \\
11\end{array}$ & $\begin{array}{l}5.1 \\
10\end{array}$ & $\begin{array}{c}5.1 \\
12\end{array}$ & $\begin{array}{l}4.3 \\
14\end{array}$ & 13.3 \\
\hline HE Azeotrope & $\begin{array}{l}4.8 \\
16\end{array}$ & 13.1 & $14^{7.9}$ & 15.1 & $\begin{array}{c}6.7 \\
16\end{array}$ & $\begin{array}{l}6.8 \\
20\end{array}$ \\
\hline Isoflurane & $2^{3.9}$ & $\begin{array}{c}3.9 \\
10\end{array}$ & $\begin{array}{l}4.0 \\
9\end{array}$ & $\begin{array}{l}4.6 \\
9\end{array}$ & ${ }^{6.5}$ & 13.9 \\
\hline Enflurane & 15 & $\begin{array}{l}5.1 \\
9\end{array}$ & $\begin{array}{l}4.8 \\
9\end{array}$ & $\begin{array}{l}6.1 \\
11\end{array}$ & $\begin{array}{l}6.8 \\
11\end{array}$ & $\begin{array}{l}5.0 \\
8\end{array}$ \\
\hline Diethyl ether & $\begin{array}{c}6.7 \\
17\end{array}$ & $\begin{array}{l}14.2 \\
21\end{array}$ & $\begin{array}{l}17.3 \\
30\end{array}$ & $\begin{array}{l}20.7 \\
39\end{array}$ & $\begin{array}{l}23.4 \\
47\end{array}$ & $\begin{array}{l}26.1 \\
48\end{array}$ \\
\hline Fluroxene & $\begin{array}{c}4.2 \\
15\end{array}$ & $\begin{array}{l}11.2 \\
18\end{array}$ & $\begin{array}{l}12.7 \\
20\end{array}$ & $\begin{array}{l}15.0 \\
22\end{array}$ & $\begin{array}{l}18.8 \\
30\end{array}$ & $\begin{array}{l}15.6 \\
29\end{array}$ \\
\hline Innovar & $\begin{array}{l}4.2 \\
14\end{array}$ & $1^{8.6}$ & $\begin{array}{l}8.1 \\
10\end{array}$ & $\begin{array}{l}6.4 \\
9\end{array}$ & $\begin{array}{l}5.4 \\
9\end{array}$ & $\begin{array}{l}12.2 \\
15\end{array}$ \\
\hline Thiopentone & $11^{3.6}$ & $9_{19}^{9.6}$ & $\begin{array}{c}8.6 \\
13\end{array}$ & $\begin{array}{c}5.1 \\
10\end{array}$ & $\begin{array}{l}5.9 \\
9\end{array}$ & $\begin{array}{l}11.6 \\
14\end{array}$ \\
\hline
\end{tabular}

*Minute volume in liters.

$\dagger$ Respiration rate/minute.

\section{Lactate, Pyruvate, L/P ratio and Excess Lactate (Table VI)}

Only diethyl ether caused a significant elevation in the fixed acids and excess lactate.

\section{Biogenic Amines and Plasma Insulin (Table VII)}

There was no clinically significant change in the plasma histamine or serotonin levels. As noted in previous reports, the alterations in the catecholamines were small and, as before, they did not correlate with elevation of $\mathrm{Pa}_{\mathrm{CO}_{2}}$ blood sugar or other chemical changes in the blood that are claimed to cause or be caused by increased secretion of adrenal epinephrine. Plasma insulin levels varied slightly with all the anaesthetics, but rose consistently with isoflurane and enflurane. This rise was greater than we saw during our experiments with hypoxia. ${ }^{12,14,15}$

\section{Rate of Recovery from Anaesthesia (Table VIII)}

Full recovery to steady ambulation took less than one hour in all but nine tests. It exceeded one hour in one test each with methoxyflurane, chloroform, isoflurane and Innovar; two with enflurane and three with thiopentone. In the tests in which thiopentone was used ( $50 \mathrm{mg} / \mathrm{kg}$ total dose), slow recovery was due to persistent drowsiness. The slow recovery of steady ambulation in the case of isoflurane and enflurane was due to muscle weakness, as these animals awakened quickly $(<10$ 


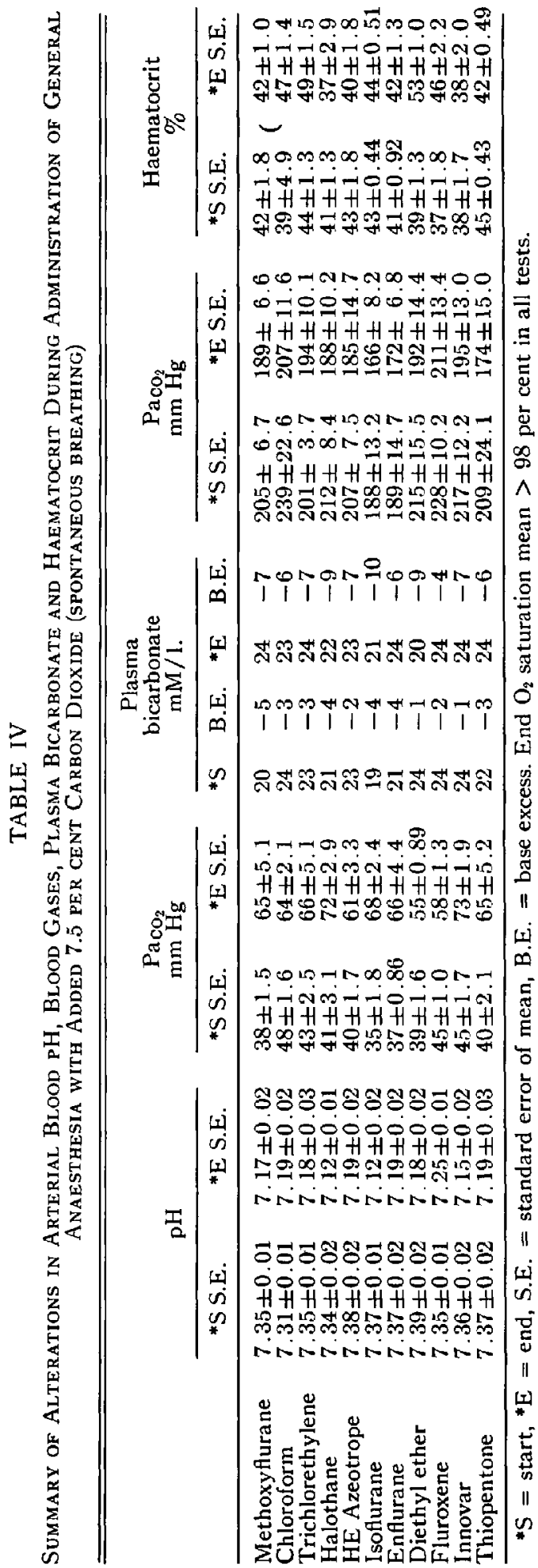




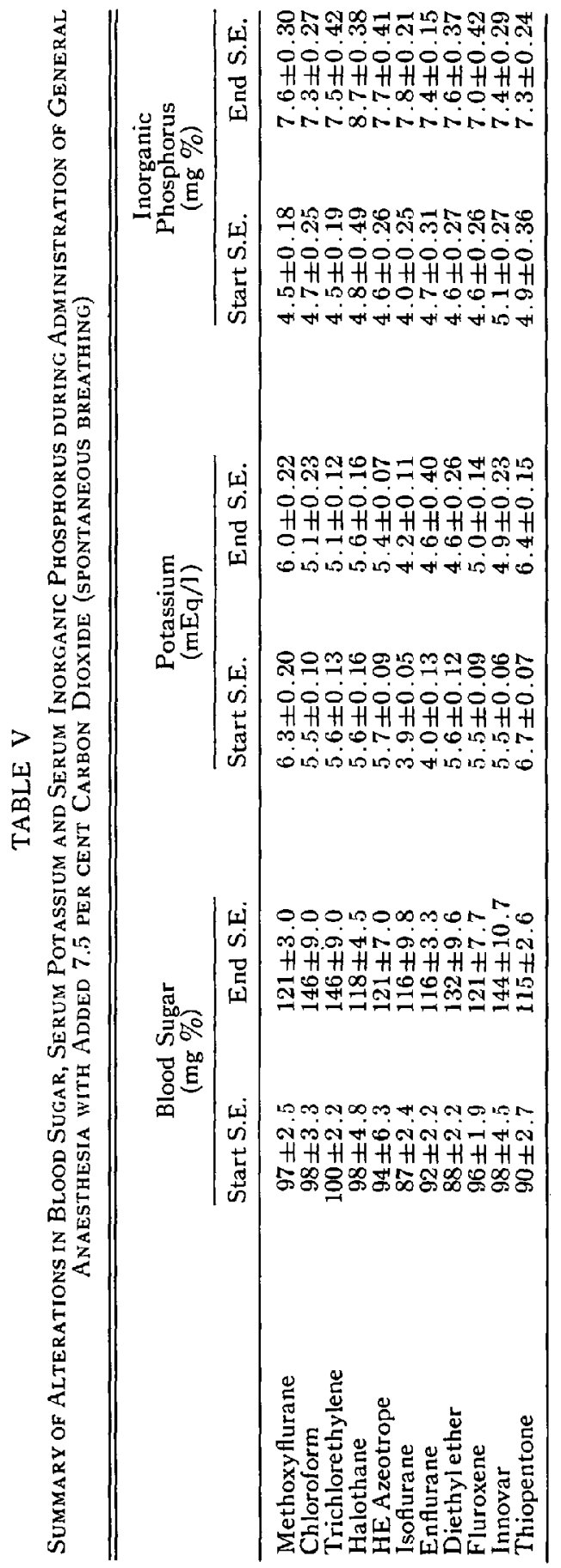




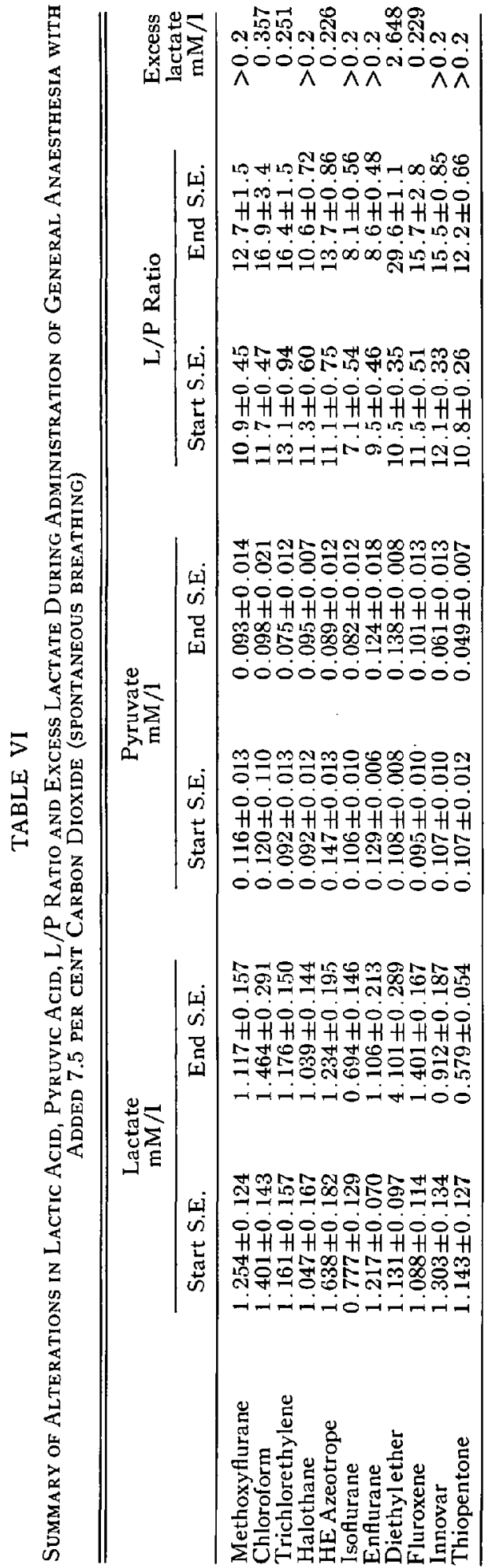


TABLE VII

Summary of Alterations in Biogenic Amines During Administration of General Anaesthesia With ENFlurane and Isoflurane wjth Added 7.5 per cent Carbon Dioxide (SPONTANEOUS BREATHING)

\begin{tabular}{lccccc}
\hline \hline & \multicolumn{2}{c}{ Enflurane } & & \multicolumn{2}{c}{ Isoflurane } \\
\cline { 2 - 3 } & Start $+\mathrm{SE}$ & End $+\mathrm{SE}$ & & Start $+\mathrm{SE}$ & End $+\mathrm{SE}$ \\
\hline Histamine $\mu \mathrm{g} / \mathrm{l}$ & $21 \pm 3$ & $21 \pm 2$ & & $15 \pm 1$ & $18 \pm 3$ \\
Serotonin $\mu \mathrm{g} / 1$ & $492 \pm \tilde{1}$ & $580 \pm 71$ & & $962 \pm 120$ & $814 \pm 107$ \\
Insulin $\mu \mathrm{U} / 1$ & $12 \pm 1$ & $24 \pm 5$ & & $16 \pm 2$ & $23 \pm 4$ \\
Epinephrine $\mu \mathrm{g} / 1$ & $1.34 \pm 0.99$ & $0.43 \pm 0.28$ & & $0.20 \pm 0.11$ & 0 \\
Norepinephrine $\mu \mathrm{g} / \mathrm{l}$ & $0.92 \pm \mathbf{0 . 5 1}$ & $0.35 \pm 0.12$ & & $0.87 \pm 0.27$ & $0.78 \pm 0.16$ \\
\hline
\end{tabular}

minutes). The latter effect was evident also for methoxyflurane. All animals were in good condition within a few hours after each test and, except for three dogs that received chloroform, were taking water and food by the following day without the need for supportive therapy. An intravenous infusion of $500 \mathrm{ml}$ of 5 per cent dextrose in water was given to the three animals that received chloroform.

\section{Discussion}

During the first hundred years after Henry Hill Hickman convinced himself of the anaesthetic properties of carbon dioxide (about 1824), sporadic studies were performed to determine the physiological effects of this metabolic by-product. It was established that exogenous carbon dioxide is a very potent stimulant of the depth of breathing; the blood pressure is elevated and the cerebrum is affected. A burst of investigative activity occurred in the 1920 's when C.D. Leake, W. Bourne, D.D. VanSlyke, R.M. Waters, W.E. Brown, and many others, showed that the anaesthetics commonly used then - chloroform, diethyl ether, nitrous oxide - especially when combined with morphine, lowered the alkali reserve of the blood, increased the hydrogen ion concentration, increased potassium excretion, and released phosphoric acid from the muscles. ${ }^{16}$ Anaesthetic gas machines were subsequently designed with carbon dioxide absorbers because some of the changes were attributed to a toxic effect of carbon dioxide accumulation.

In spite of this knowledge, carbon dioxide tanks were placed on anaesthetic machines and carbon dioxide was frequently added to the inhaled anaesthetics to accelerate induction and added to oxygen at the end of an operation to accelerate emergence. In the days before the pin-index system was inaugurated, this led to fatal accidents and most anaesthetists decided that it was prudent to remove the carbon dioxide tanks from anaesthetic machines.

About 1950, it became apparent that even moderate hypercapnoea (to about $65 \mathrm{mmHg}$ ) could sometimes have deleterious effects, particularly when cyclopropane was used. ${ }^{1,17}$ Since then, it has been customary to maintain isocapneic or hypocapneic conditions during anaesthesia and the recovery period.

In the past 25 years, many aspects of the effects of carbon dioxide on the circulation of the brain, on intracranial pressure, the heart, the central and autonomic nervous system, on neuromuscular transmission and on cardiorespiratory function at various blood tensions of carbon dioxide have been studied. ${ }^{2,3,7}$ Although much 


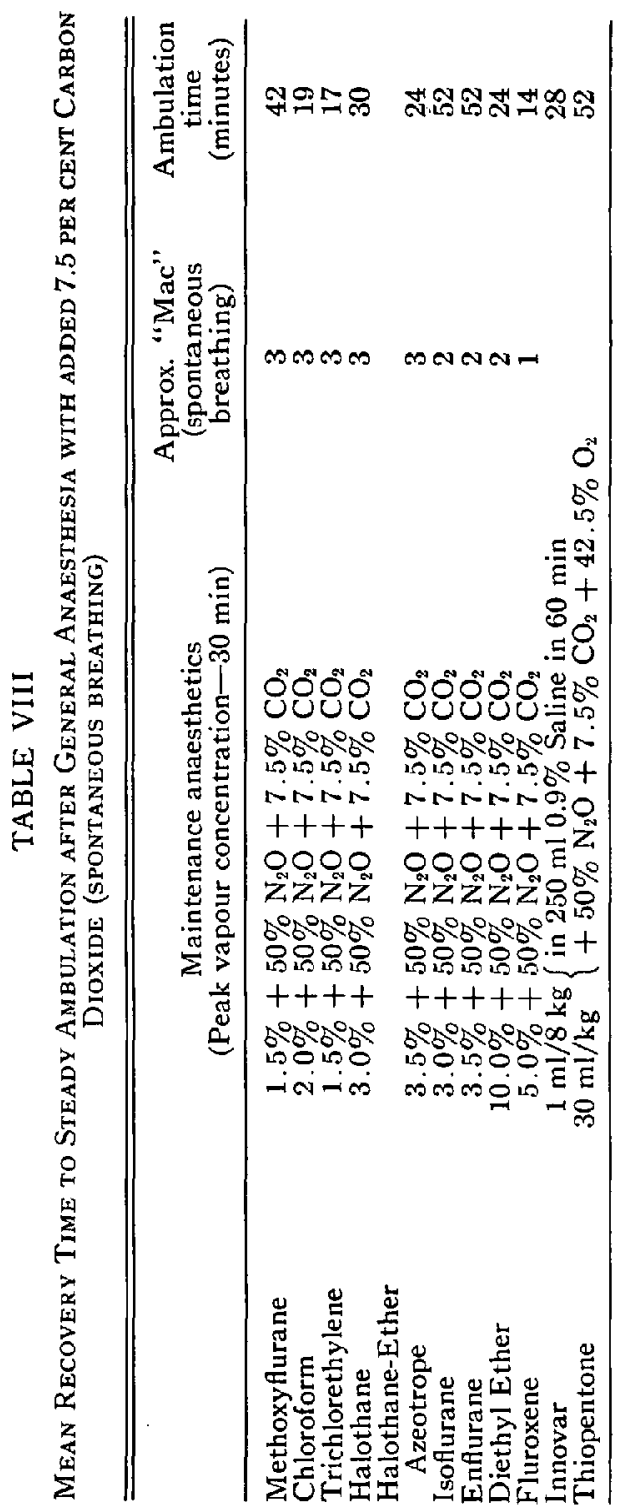


knowledge has been gained, there still remains considerable controversy as to whether or not a moderate increase or decrease ( \pm 20 torr) of carbon dioxide tension in the blood (normal 35 to 45 torr) has a beneficial effect during anaesthesia.

Wide experience with induced hypocapnia by the proponents of passive hyperventilation appears to show that a reduction in the $\mathrm{Pa}_{\mathrm{CO}_{2}}$ has clinical advantages over isocapneic conditions during anaesthesia and this appears to hold true with all currently used inhalation anaesthetics, including enflurane and isoflurane. ${ }^{14,15,18,19}$

The effects of hypercapnia are more difficult to define in association with general anaesthesia because there are so many extraneous factors that influence the cardiorespiratory response. These factors are not influential during the hypocapnia of passive hyperventilation. Severinghaus, Larson, Munson and others have studied and reviewed some of these influences. ${ }^{20}$

In this study, we attempted to avoid or to control most of the interfering factors. Premedication with morphine or other strong analgesics, with or without atropine, certainly causes great obfuscation in this respect because these drugs depress the respiratory centers and the medullary chemoreceptor responses to hypercapnia, and thus affect the central control of respiration and tend to augment the hyperventilation and hypotension that can result from even light general anaesthesia. ${ }^{21,22}$ Therefore, no premedication was used. Muscle relaxants were not used. The insertion of a tracheal tube maintains an unobstructed airway but, unless the largest possible size is used, airway resistance and the work of breathing may be increased and may cause increased production of endogenous carbon dioxide and promote tachypnoea. Therefore, a large tracheal tube was used in all tests. A non-rebreathing system with a low-resistance expiratory valve is essential, otherwise it is virtually impossible to maintain a relatively steady level of carbon dioxide in the blood. The loss of heat from the body, which usually occurs during a surgical depth of anaesthesia, must also be kept to a minimum because hypothermia decreases the cardiorespiratory response to hypercapnia. For this reason, we kept the laboratory warm. The administration of 50 per cent nitrous oxide (with about 40 per cent oxygen) probably has little effect on the respiratory response to carbon dioxide, although it augments the analgesic and hypnotic effects of general anaesthesia, ${ }^{23}$ and possibly has a sympathetic stimulating effect. ${ }^{24,25}$ The only factor that may have influenced our experiments, aside from the anaesthetics themselves, was having the dog lie on its side after induction of anaesthesia. This position may affect the compliance and perfusion of the lower lung, but it prevents compromising the blood flow to the head which occurs if the dog is strapped in an upright position.

It is almost heresy now to suggest that the administration of a low concentration of carbon dioxide (5.0-7.5 per cent) during anaesthesia is probably innocuous, and that if it is desirable to permit spontaneous breathing with general anaesthesia the addition of carbon dioxide may be efficacious. This study did not reveal any of the noxious effects that have been shown in conscious dogs. In the anaesthetized animal, some undesirable effects of the inhalation anaesthetics were averted when carbon dioxide was added. Pulmonary ventilation was clearly stimulated in a surgical depth of anaesthesia with methoxyflurane, chloroform, trichlorethylene, 
halothane-ether azeotrope, diethyl ether, fluroxene, Innovar and thiopentone. Severe respiratory depression by halothane, isoflurane and enflurane was averted (Table IX). Although heart rate was increased with all agents except Innovar, the hypertensive effect of carbon dioxide was not striking but, again, it appeared to prevent severe hypotension that usually occurs with deep anaesthesia. If the product of heart rate and systolic blood pressure (the Fenn effect) is a valid indication of the oxygen requirement of the myocardium, ${ }^{26}$ then diethyl ether, fluroxene and thiopentone are probably the only agents tested that may cause some concern (Table X). Cardiac arrhythmias were virtually absent. Clearly, hypercapnia increases intracranial pressure, and carbon dioxide should not be given to patients suffering from this condition. ${ }^{27}$ In patients with chronic obstructive lung disease, carbon dioxide is not helpful and its administration may aggravate arterial hypoxaemia. $^{2}$

There are conflicting data regarding the autonomic nervous system responses to carbon dioxide..$^{28,29,30}$ The secondary metabolic effects ${ }^{29,31}$ during general anaesthesia cause blood sugar changes that are similar to those observed under isocapnoea and are usually due to increased glycogenolysis; serum potassium still decreases during most inhalation anaesthetics, with increased urinary excretion by an unknown mechanism, and serum inorganic phosphorus consistently rises probably for the reason described by Bourne. ${ }^{16}$ There are no other metabolic disturbances evident as reflected by the demonstration of excess lactate and changes in biogenic amines, except with diethyl ether. It appears therefore that the only absolute contraindications to permitting hypercapnia are chronic obstructive lung disease and intracranial lesions. ${ }^{2,27}$

The hypotension and bradycardia that developed with the agents cited were probably due to the peripheral vasodilatation that is a characteristic effect of carbon dioxide, although depression of myocardial contractility and reduced stroke volume by the primary agent cannot be ruled out.

It was evident that, during anaesthesia, carbon dioxide was usually a stronger stimulus to respiration than is hypoxia when these data were compared with our previous studies. ${ }^{10,12,32}$ It is now even suggested that carbon dioxide may be added during general anaesthesia for hypertensive patients when passive hyperventilation is employed, in order to prevent postoperative pulmonary atelectasis (collapse), as well as to improve cerebral blood flow and prevent depressed cerebral metabolism. ${ }^{33,34}$

These data again showed that diethyl ether is the only general anaesthetic currently in use that consistently causes metabolic acidosis. It was interesting to note that the administration of carbon dioxide appeared partially to suppress the increase in excess lactate with this agent. ${ }^{9,10,12}$

None of the tests with enflurane caused clinical signs of neuromuscular disturbance, although the addition of carbon dioxide to the inhaled vapour might be expected to do so.

\section{Summary AND CoNClusions}

General anaesthesia with enflurane, isoflurane, seven other inhalational agents and two parenteral anaesthetics was administered to dogs, together with nitrous 


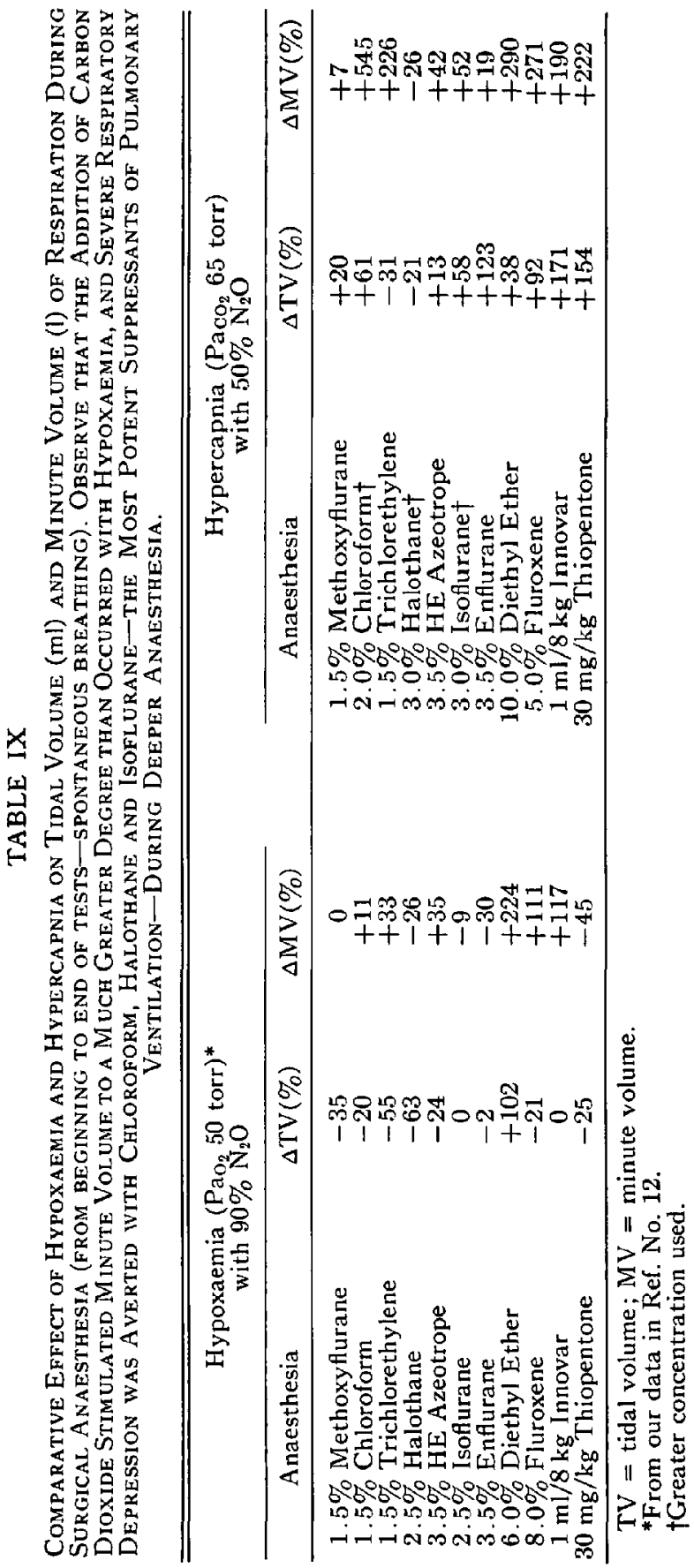


TABLE $X$

Comparative Effect of Hypoxaemia and Hypercapnia on Myocardial Oxygen Requirement during Surgical Anaesthesia as Reflected by Heart Rate $X$ Sys-

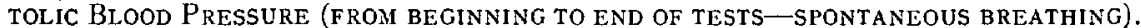
Observe that Halothane, Isoflurane, Halothane-Ether Azeotrope, Enflurane, Methoxyflurane and Innovar with Added Carbon Dioxide are Probably Efficacious in this Respect and may be Useful in the Patient with Deficient Myocardial Reserve. Diethyl Ether, Thiopentone and Trichlorethylene, on the Other Hand, are Probably Contraindicated in such Patients

\begin{tabular}{lllll}
\hline \multicolumn{2}{c}{ Hypoxaemia $\left(\mathrm{PaO}_{2} 50\right.$ torr) } & & \multicolumn{2}{c}{ Hypercapnia (Paco. 65 torr) } \\
\cline { 4 - 5 } Anaesthesia with $90 \% \mathrm{~N}_{2} \mathrm{O}$ & $\% \Delta$ & & Anaesthesia with $50 \% \mathrm{~N}_{2} \mathrm{O}$ & $\% \Delta$ \\
\hline $\mathbf{1 . 5 \%}$ Methoxyflurane & -32 & & $\mathbf{1 . 5 \%}$ Methoxyflurane & -35 \\
$\mathbf{1 . 5 \%}$ Chloroform & +3 & $2.0 \%$ Chloroform & +9 \\
$\mathbf{1 . 5 \%}$ Trichlorethylene & +3 & & $1.5 \%$ Trichlorethylene & +32 \\
$2.5 \%$ Halothane & -39 & $3.0 \%$ Halothane & -46 \\
$3.5 \%$ HE Azeotrope & -13 & $3.5 \%$ HE Azeotrope & -45 \\
$2.5 \%$ Isoflurane & -34 & $3.0 \%$ Isoflurane & -46 \\
$3.5 \%$ Enflurane & -42 & $3.5 \%$ Enflurane & -37 \\
$6.0 \%$ Diethyl Ether & +41 & $10.0 \%$ Diethyl Ether & +83 \\
$8.0 \%$ Flurosene & +42 & $5.0 \%$ Fluroxene & +32 \\
$1 \mathrm{ml} / 8 \mathrm{~kg}$ Innovar & +2 & $1 \mathrm{ml} / 8 \mathrm{~kg}$ Innovar & -49 \\
$30 \mathrm{mg} / \mathrm{kg}$ Thiopentone & +29 & $30 \mathrm{mg} / \mathrm{kg}$ Thiopentone & +37 \\
\hline
\end{tabular}

*From our data in Ref. No. 12.

oxide, oxygen and 7.5 per cent carbon dioxide. Breathing was spontaneous throughout. Each of the tests lasted 90 minutes.

Arterial blood gases, urine output, blood chemistry (including electrolytes, biogenic amines, lactate and pyruvate), pulmonary ventilation, electrocardiogram, blood pressure and heart rate were measured by standard laboratory procedures before and after the tests.

The administration of carbon dioxide augmented pulmonary ventilation with all the anaesthetics tested. Marked tachypnoea developed with chloroform, trichlorethylene and diethyl ether. Other effects observed were the development of mild respiratory acidosis $\left(\mathrm{pH} \sim 7.20 ; \mathrm{Pa}_{\mathrm{CO}_{2}} \sim 65\right)$ with all anaesthetics. Metabolic acidosis also occurred with some anaesthetics, but was prominent only with diethyl ether. A rise in blood sugar and serum inorganic phosphorus and a reduction in serum potassium was seen consistently, but changes in other laboratory tests were not significant. Mean recovery of steady ambulation occurred in all animals in less than one hour. Slowest recovery occurred with methoxyflurane, isoflurane and enflurane, due to their muscle relaxant effect, and with thiopentone, due to its hypnotic effect.

The addition of carbon dioxide to most general anaesthetics administered with 50 per cent nitrous oxide does not prevent the development of hypotension, but cardiac arrhythmias may be suppressed. Myocardial oxygen requirements are probably not increased except with trichlorethylene, diethyl ether, fluroxene and thiopentone.

It appears that, in the absence of chronic obstructive lung disease, intracranial lesions or increased intracranial pressure, the administration of a low concentration of carbon dioxide may be innocuous during inhalation or parenteral anaesthesia when spontaneous breathing may be desired. It may be useful to support 
pulmonary ventilation and oxygenation of the blood and tissues, and to reduce cerebral vasoconstriction in hypertensive patients.

\section{RÉSUMÉ}

Afin de vérifier la possibilité de conserver une respiration spontanée efficace sous anesthésie générale grâce à l'effet respiratoire stimulant du $\mathrm{CO}_{2}$, on a anesthésié des chiens avec neuf différents agents d'inhalation (dont l'enflurane et l'isoflurane) et deux agents injectables additionnées en plus de l'oxygène et du protoxyde d'azote de $\mathrm{CO}_{2}$ à 7.5 pour cent. Chaque épreuve a duré 90 minutes.

On a mesuré, avant et après l'épreuve, les gaz artériels, le débit urinaire, la chimie sanguine (électrolytes, amines endogènes, lactates, pyruvates), la ventilation pulmonaire, l'électrocardiogramme, la tension artérielle et la fréquence du pouls.

L'addition de $\mathrm{CO}_{2}$ a augmenté la ventilation pulmonaire avec tous les anesthésiques employés pour devenir une tachypnée marquée avec le chloroforme, le trichlorétylène et l'éther.

On a naturellement observé une acidose respiratoire légère avec tous les agents, ( $\mathrm{pH} 7,20, \mathrm{PCO}_{2} 65 \mathrm{~mm} \mathrm{Hg}$ ) et aussi une acidose métabolique sans importance avec quelques agents sauf avec l'éther où l'acidose était franchement marquée.

On a vu se reproduire régulièrement une augmentation de la glycémie et du taux plasmatique du phosphore inorganique et la diminution de la kaliémie ; les modifications des autres tests n'ont présenté aucun écart significatif.

Les animaux ont recouvré l'aptitude à la marche en moyenne une heure après l'expérience ; la récupération était plus lente avec le méthoxyflurane, l'isoflurane et l'enflurane, (à cause possiblement des effets myorésolutifs de ces agents) et avec le thiopentone à cause de son effet hypnotique prolongé. L'addition de $\mathrm{CO}_{2}$ à la plupart des agents anesthésiques administrés avec du protoxyde d'azote à 50 pour cent n'empêche pas la survenue d'hypotension mais pourrait diminuer l'incidence d'arythmies. Les besoins d'oxygène du myocarde ne sont probablement pas augmentés sauf avec le trichlorétylène, l'éther, le fluroxène et le thiopentone.

Il semble donc qu'en l'absence de maladie pulmonaire obstructive chronique, de lésion cérébrale ou d'hypertension crânienne, l'inhalation de faibles concentrations de $\mathrm{CO}_{2}$ durant l'anesthésie générale permet de conserver sans danger une ventilation spontanée efficace.

Ce procédé peut s'avérer utile chez des malades hypertendus pour stimuler la ventilation pulmonaire, l'oxygénation du sang et des tissus et réduire le vasoconstriction cérébrale.

\section{ACKNOWLEDGMENT}

This project was supported by grants-in-aid from Ayerst Laboratories, AIRCO Inc., U.S.P.H.S. Grant 05402-04,5 and by The Division of Research Facilities and Resources of N.I.H. (Grant FR00353).

The authors appreciate the excellent technical assistance of the following members of this project: Christina Bisset, R.N., Robert Gelder, B.S., R.T., George D. Mann, R.T., Sandra Menjik, B.S., R.T. and John W. White, B.A. 


\section{REFERENCES}

1. Miller, F.A., Brown, E.B., Bucklex, J.J., VanBergen, F.H., \& Vafco, R.L. Respiratory acidosis: its relationship to cardiac function and other physiologic mechanisms. Surgery 32: $171(1952)$.

2. Cherniack, R.M., Cherniack, L., \& Naimark, A. Respiration in Health and Disease (2nd ed.) Philadelphia, Saunders (1972).

3. Nunn, J.F. The effects of hypercapnia. Chapter in Modern Trends in Anaesthesia, No. 2, Editors: Evans, T.F. \& Gray, T.C., London, Butterworth (1962).

4. Homi, J., Smart, J.F., \& Wasmuth, C.E. Cerebrovascular response of arterioscleratic patients to hypercapnia during general anaesthesia. Acta anaesth. scand. Suppl. 23: 629 (1966).

5. Broom, B. \& Selick, B.A. Controlled hypercapnia in open heart surgery under hypothermia Lancet $i i: 452$ (1965).

6. Wells, B.A., Keats, A.S., \& Cooley, D.A. Increased tolerance to cerebral ischemia produced by general anesthesia during during temporary carotid occlusion. Surgery $54: 216$ (1963).

7. Sokoloff, L. The action of drugs on the cerebral circulation. Pharmacol. Rev. 11: 1 (1959).

8. Brown, W.E., Henderson, V.E., Kennedx, A.S., \& Lucas, G.H.W. On the co-administration of carbon dioxide with nitrous oxide in anesthesia. Anesth. \& Analg. 9: 136 (1930).

9. Dовкin, A.B., Byles, P.H., \& Neville, J.F., JR. Neuroendocrine and metabolic effects of general anaesthesia during spontaneous breathing, controlled breathing, mild hypoxia and mild hypercarbia. Canad. Anaesth. Soc. J. 13:130 (1966).

10. Doekin, A.B., Byles, P.H., Africa, B.F., \& Neville, J.F., Jr. The neuroendocrine and metabolic effects of general anaesthesia associated with acute hypoxia and acute hypercapnia. Canad. Anaesth. Soc. J. 14: 442 (1967).

11. Neville, J.F., JR, \& Gelder, R.L. Modified enzymatic methods for the determination of $\mathrm{L}-(+)$-lactic acid and pyruvic acid in blood. Amer. J. Clin. Path. 55: 152 (1971).

12. Dobkin, A.B., Byles, P.H., \& Levy, A.A. Enflurane (Ethrane) and Isoflurane (Forane). A comparison with nine general anaesthetics during stress of hypoxia (spontaneous breathing). Canad. Anaesth. Soc. J. 20: 782 (1973).

13. Morgan, C.R. \& Lazarow, A. Immunoassay of insulin: two antibody system. Diabetes 12: 115 (1963).

14. Byles, P.H., Dobkin, A.B., Fercuson, J.H., \& Levy, A.A. Forane (compound 469): Crossover comparison with enflurane (Ethrane), Halothane and Methoxyllurane in dogs. Canad. Anaesth. Soc. J. 18: 376 (1971).

15. Dobkin, A.B., Byles, P.H., Arandia, H.Y., Ghanooni, S., Nishioka, K., \& Levy, A.A. Comparative metabolic responses to halogenated anaesthetics Acta anaesth. scand, 16: 69 (1972).

16. Bourne, Wesley. Mysterious Waters to Guard, Springfield, C.C. Thomas (1955).

17. DoBkin, A.B. \& VAN BERGEN, F.H. The study of hypercapnia with a mass spectrometer. Bulletin of Univ. of Minnesota 23: 410 (1952).

18. Geddes, I.C. \& Grax, T.C. Hyperventilation for the maintenance of anaesthesia. Lancet ii: 4 (1959).

19. Dobkin, A.B., Byles, P.H., Africa, B.F., \& Levy, A.A. Enflurane (Ethrane) and Isoflurane (Forane): A comparison with nine general anaesthetics administered with passive hyperventilation (in preparation).

20. Severinghaus, J.W. \& Larson, C.P., Jr. Respiration in Anesthesia, Chapter 24 in Handbook of Physiology, Section 3: Respiration, Vol. II, Fenn, W.O. \& Rahn, H., editors. Washington, Amer. Physiol. Soc. (1965).

21. EckenhofF, J.E. \& OEch, S.R. The effect of narcotics and antagonists upon respiration and circulation in man. Clin. Pharmacol, \& Ther. 1: 483 (1960).

22. Weil, J.V., MCCullough, R.E., Kline, J.S., \& Soudal, I.E. Diminished ventilatory response to hypoxia and hypercapnia after morphine. New Engl. J. Med. 292: 1103 (1975).

23. Wong, K.C., Martin, W.E., Horniein, T.F., Freund, F.G., \& Everetr, J. The cardiovascular effects of morphine sulfate with oxygen and with nitrous oxide in man. Anesthesiology 38: 542 (1973).

24. Hornbein, T.F., Martin, W.E., Bonica, J.J., Freund, F.G., \& Parmentier, P. Nitrous oxide effects on the circulatory and ventilatory response to halothane. Anesthesiology 31: $250(1969)$. 
25. Horneein, T.F. \& Sørenson, S. The Chemical Regulation of Ventilation, Chapter 23 in Physiology and Biophysics, Vol. II, 20th ed., Ruch, T.C. \& Patton, H.D., editors. Philadelphia, Saunders and Company (1974).

26. Braunwald, E. Control of myocardial oxygen consumption, Am. J. Cardiol, 27: 416 (1971).

27. Paulsos, O.B. Editorial: Intracranial hypertension. Anesthesiology $36: 1$ (1972).

28. Meduna, L.J. Carbon dioxide therapy. Springfiield, C.C. Thomas (1950).

29. TENNEY, S.M. The effect of carbon dioxide on neurohumoral and endocrine mechanisms. Anesthesiology $21: 674$ (1960).

30. Price, H.L. Effect of carbon dioxide on the cardiovascular system. Anesthesiology 21: 652 (1960).

31. Nahas, G. \& Schaefer, K.E. (editors). Carbon dioxide and metabolic regulations. New York, Springer-Verlag (1974).

32. Dobkin, A.B. \& Byles, P.H. Anesthesia and Respiration, Chapter 1 in Ventilators and Inhalation Therapy, 2nd. ed., editor, Dobkin, A.B. Boston, Little Brown and Co. (1972).

33. Fö̈x, P. \& Prys-Roberts, C. Anaesthesia and the hypertensive patient. Brit. J. Anaesth. 46: 575 (1974).

34. Alberti, E., Hoyer, S., Hamer, J., Stoekel, H., Packschiess, P., \& Weinhardt, F. The effect of carbon dioxide on cerebral blood flow and metabolism in dogs. Brit. J. Anaesth. 47: 941 (1975). 